\title{
PRÓBA MODYFIKACJI POWIERZCHNI CZYNNEJ OGNIWA FOTOWOLTAICZNEGO POPRZEZ ZMIANE PARAMETRÓW PODŁOŻA
}

\begin{abstract}
Sputtering magnetronowy jest techniką napylania warstw cienkich znajdującą coraz większe zastosowanie w procesach wytwarzania elektroniki i ogniw fotowoltaicznych [1,2]. Celem prezentowanych w artykule prac badawczych, jest analiza możliwości zastosowania podłoża alternatywnego do powszechnie stosowanych i tym samym osiągnięcie zmian topografii warstw otrzymywanych w procesie sputteringu magnetronowego. Zaburzenie topografii podłoża może skutkować większym uporządkowaniem struktury warstwy, co oznacza bardziej jednolitą powierzchnię, lub zjawiskiem całkowicie odwrotnym. Oba rezultaty są pożądane z punktu widzenia zastosowań produkcyjnych. Z jednej strony poszukuje się cienkich i jednolitych warstw, a z drugiej warstw o zmodyfikowanej topografii. Według autora, modyfikacja topografii warstw pochłaniających promieniowanie, może doprowadzić do zwiększenia powierzchni czynnej ogniwa fotowoltaicznego a co za tym idzie zwiększyć jego wydajność [3]. W czasie eksperymentów autor używał jako podłoża standardowego szkła laboratoryjnego (float) oraz laminatu (papier z żywicą). Dokonano serii naniesień warstw cienkich, celem otrzymania kompletnego ogniwa. Ogniwa na szkle jak i na laminacie były wykonane w tych samych warunkach i parametrach kolejnych procesów. Kolejne warstwy wchodzące w skład budowy ogniwa były tak nanoszone, by istniała możliwość ich późniejszej analizy (stosowano odpowiednie przesłony). Po wykonaniu ogniw, została sprawdzona ich wydajność kwantowa, którą odniesiono do obserwacji otrzymanych w wyniku skanowania AFM kolejnych warstw.
\end{abstract}

Słowa kluczowe: ogniwa fotowoltaiczne, modyfikacja topografii warstwy, wydajność kwantowa, nanoszenie warstw

\section{Wprowadzenie}

Napylanie $\mathrm{z}$ wykorzystaniem sputteringu magnetronowego jest jedną z technik wytwarzania warstw ultracienkich [4]. Do głównych zalet tej metody należą: brak konieczności stosowania wysokich temperatur w czasie procesu,

\footnotetext{
${ }^{1}$ Tomasz Grudniewski, Państwowa Szkoła Wyższa im. Papieża Jana Pawła II w Białej Podlaskiej, Wydział Nauk Ekonomicznych i Technicznych, Zakład Informatyki, ul. Sidorska 95/97, 21-500 Biała Podlaska; tel. 833449908; knt@ pswbp.pl
} 
oraz możliwość użycia substancji nieprzewodzących jako podłoże lub substancję napylaną. Proces sputteringu zachodzi w komorze próżniowej, do której wprowadza się gaz, najczęściej jest to argon wysokiej czystości rzadziej z niewielką domieszką tlenu lub azotu (sputtering reaktywny), następnie do targetu wykonanego z substancji, którą się napyla, podłączane jest stały lub zmienny sygnał sterujący, który doprowadza do jonizacji gazu w komorze [5,6]. Cząsteczki plazmy kierowane przez magnesy znajdujące się pod targetem bombardują jego powierzchnię i doprowadzają do wybijania cząstek, które następnie osadzają się na pierwszej napotkanej powierzchni. Dotychczas autor próbował stosować metody modyfikacji topografii poprzez m.in. przesłony mechaniczne - eksperymenty te nie dały jednak zadowalających rezultatów. Celem pracy autora było zbadanie możliwości modyfikacji topografii nanoszonych warstw poprzez wprowadzenia nierównego podłoża, tak by zwiększyć powierzchnię aktywną, co jest pożądane przy badaniach nad ogniwami fotowoltaicznymi. Eksperymenty były przeprowadzane z wykorzystaniem magnetronu pracującego w trybie odgórnym (target znajduje się nad podłożem, na które nanoszone są warstwy). Jako podłoża ogniw wykorzystano szkiełka mikroskopowe typu float oraz płytki pcb (laminat - papier utwardzany żywicą).

\section{Opis procedury badawczej}

W eksperymencie do nanoszenia kolejnych warstw ultracienkich ogniw fotowoltaicznych, użyto maszyny firmy Alliance Concept Line 440.Urządzenie to posiada możliwość instalacji czterech źródeł materiałów (targetów), odpowiednie oprogramowanie procesu, przesuwanie próbką (powstającym ogniwem) pod kolejnymi targetami umożliwia budowę zaawansowanych struktur. Urządzenie jest $\mathrm{z}$ powodzeniem stosowane $\mathrm{w}$ komercyjnej produkcji pojedynczych warstw jak i nawet całych paneli fotowoltaicznych [4]. Schematyczny wygląd ogniw wytwarzanych na potrzeby prezentowanych eksperymentów przedstawia Rys. 1. W Tabeli 1 zawarto parametry procesów, które wykorzystywano przy tworzeniu kolejnych warstw. Jak łatwo zaobserwować użyte w eksperymentach ogniwa są zbudowane odwrotnie $-\mathrm{z}$ innej strony znajduje się podłoże. Należy tutaj wspomnieć, że podłoże laminatowe było pokryte grubą warstwą miedzi (do zastosowań w mi-

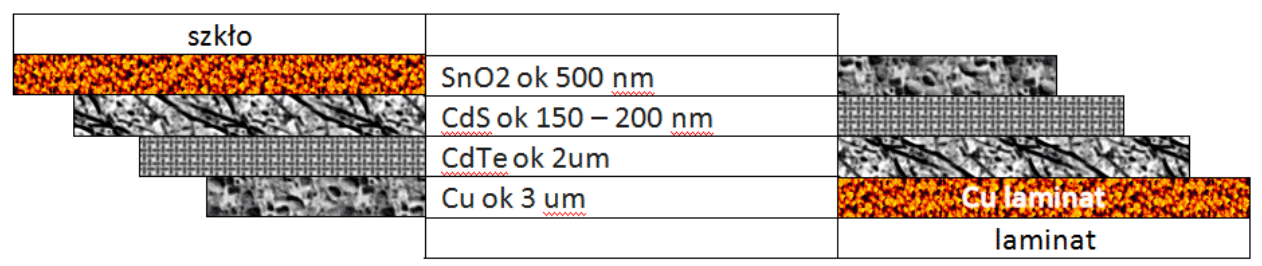

Rys. 1. Schemat budowy ogniw przygotowywanych do eksperymentów oraz grubości naniesionych warstw

Fig. 1. Scheme of the prepared cells and thickness of the applied layers 
Tabela 1. Zestawienie parametrów wykonania poszczególnych warstw w analizowanych przetwornikach

Table 1. Layers sputtering process parameters

\begin{tabular}{|l|l|}
\hline Warstwa & \multicolumn{1}{|c|}{ Parametry procesów nanoszenia } \\
\hline $\mathrm{SnO} 2$ & $\begin{array}{l}\text { moc generatora: } 700 \mathrm{~W} / \mathrm{RF} \text {; temperatura: } 250{ }^{\circ} \mathrm{C} ; \\
\text { gazy Ar/O2: } 100 / 5 \mathrm{sccm} \text {; czas } 10 \text { min. }\end{array}$ \\
\hline $\mathrm{CdS}$ & $\begin{array}{l}\text { moc generatora: } 1000 \mathrm{~W} / \mathrm{RF} \text {; temperatura: } 150{ }^{\circ} \mathrm{C} ; \\
\text { gaz Ar: } 100 \mathrm{sccm} \text {; czas } 7,5 \text { min. }\end{array}$ \\
\hline $\mathrm{CdTe}$ & $\begin{array}{l}\text { moc generatora: } 800 \mathrm{~W} / \mathrm{RF} \text {; temperatura: } 150{ }^{\circ} \mathrm{C} ; \\
\text { gaz Ar: } 100 \mathrm{sccm} \text {; czas } 40 \text { min. }\end{array}$ \\
\hline $\mathrm{Cu}$ & $\begin{array}{l}\text { moc generatora: } 600 \mathrm{~W} / \mathrm{DC} ; \text { temperatura: } 25^{\circ} \mathrm{C} ; \\
\text { gaz Ar: } 100 \mathrm{sccm} \text {; czas } 5 \text { min. }\end{array}$ \\
\hline
\end{tabular}

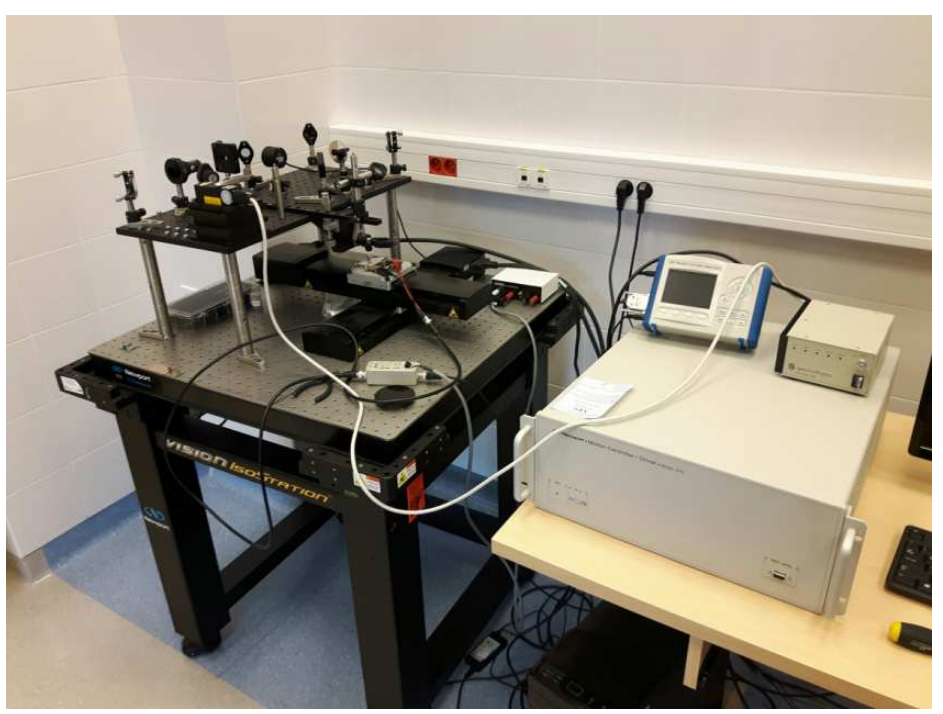

Rys. 2. Układ pomiarowy służący do powierzchniowego mapowania zmian wydajności ogniw fotowoltaicznych

Fig. 2. The measuring setup used for the photovoltaic cells surface efficiency mapping

kroelektronice). By usunąć zanieczyszczenia i spowodować uzyskanie jak najcieńszej warstwy, płytki poddano trawieniu (bombardowaniu wysoko energetycznymi cząstkami, celem wybicia atomów miedzi - do pożądanej grubości).

Grubości warstw określono na podstawie wcześniejszych eksperymentów dotyczących powiązania warunków procesu $\mathrm{z}$ pomiarami z wykorzystaniem elipsometru (Horiba Uvisel-2). Pomiarów wydajności i generowanej mocy, wykonanych ogniw dokonano z zastosowaniem dwóch układów symulatorów firmy Oriel. Wykorzystane układy umożliwiały pomiar wydajności kwantowej przetworników w odniesieniu do długości fali oświetlającej (Oriel IQE-200) oraz dla 
światła białego (Oriel Sol 3A). Porównania topografii wybranych próbek dokonano stosując mikroskop sił atomowych (NT-MDT Ntegra Spectra C). Mapowanie wydajności ogniw fotowoltaicznych wykonano stosując zestaw pomiarowy pokazany na Rys. 2. Układ z Rys. 2. posiada oprogramowanie i urządzenia kontrolno-pomiarowe umożliwiające analizę zmian wydajności ogniw w różnych punktach. Wyniki badań z wykorzystaniem zestawu z Rys. 2. mogą posłużyć jako informacja o jakości procesu wykonania lub pokazać zmiany wynikające z fluktuacji topografii kolejnych warstw.

\section{Metodyka i wyniki badań}

Pierwszym zbadanym zagadnieniem był pomiar wydajności kwantowej wybranych (najbardziej reprezentatywnych wg autora) ogniw w zależności od długości fali oświetlającej (Rys. 3). Pomiary wydajności kwantowej wykonano dla określonego pola powierzchni ogniw.

Kolejnym parametrem było sprawdzenie mocy generowanej przez ogniwa w odniesieniu do długości fali oświetlającej (Rys. 4). Zebrane dane dotyczą ogniwa fotowoltaicznego wykonanego na szkle jak i na laminacie.

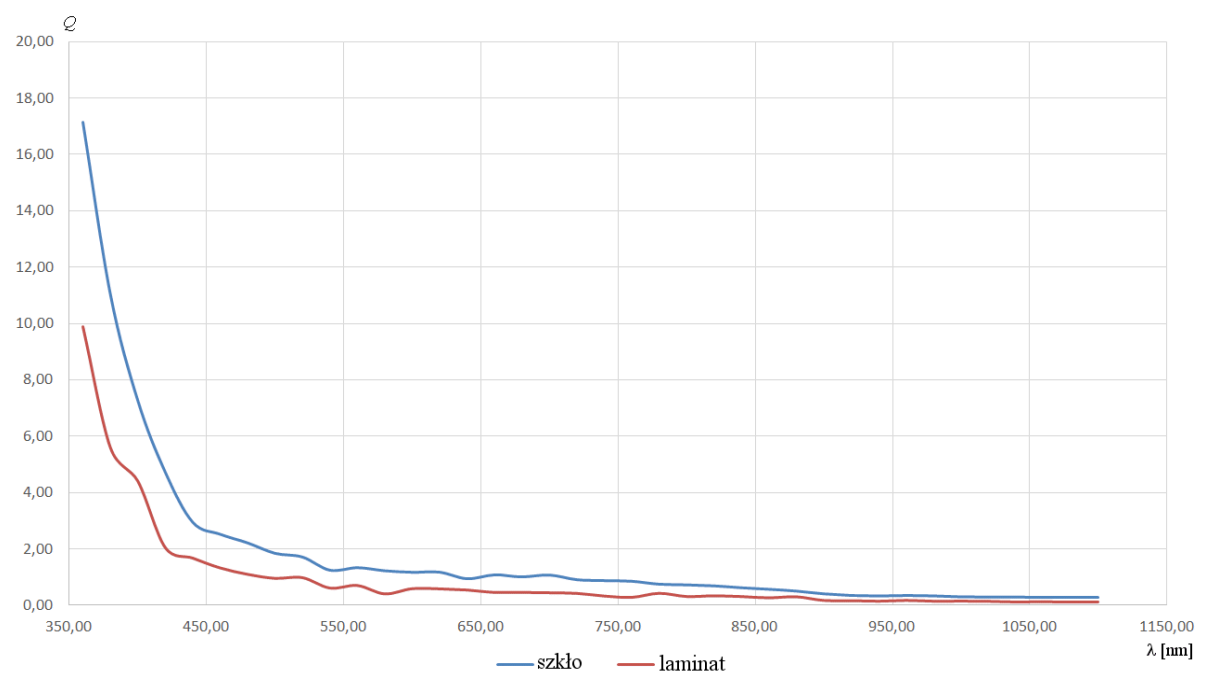

Rys. 3. Wydajność kwantowa ogniw (szkło/laminat)

Fig. 3. Cells quantum efficiency (glass / fiberglass) 


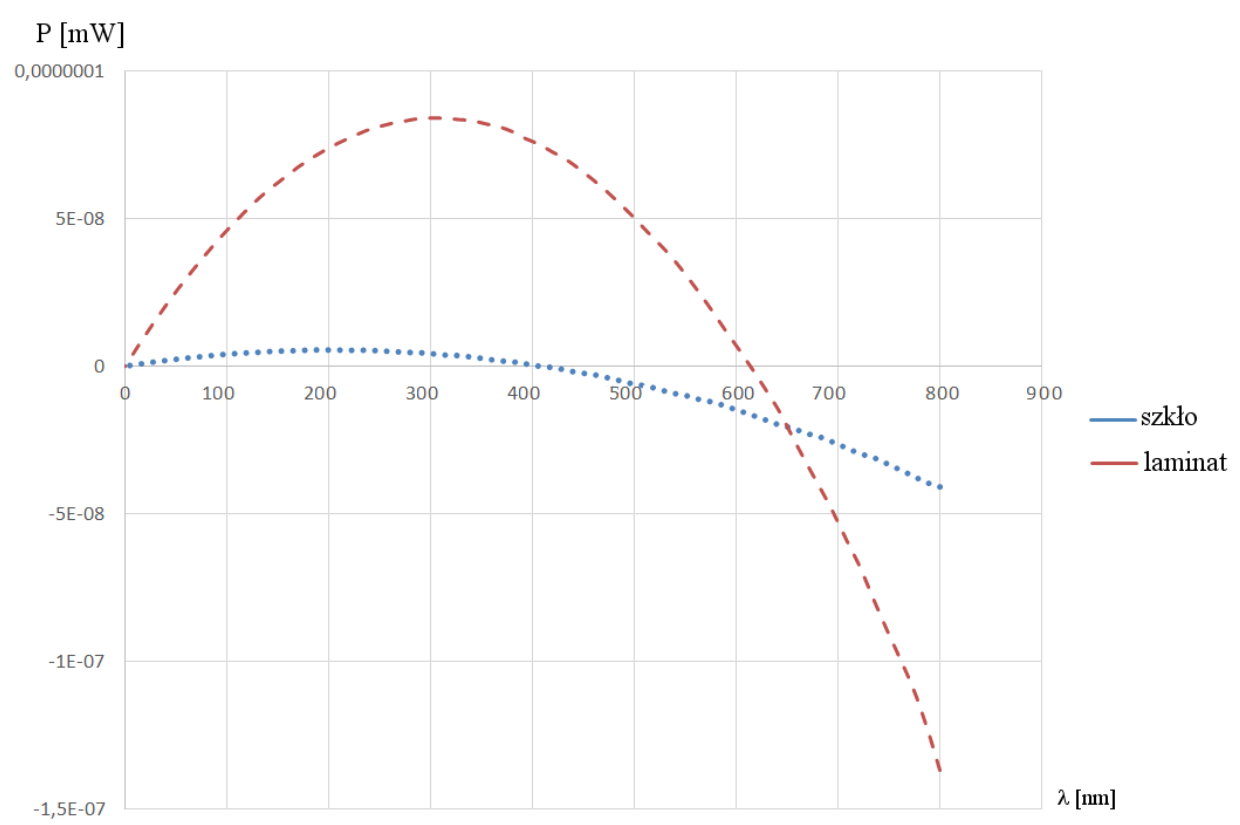

Rys. 4. Moc wybranych ogniw w odniesieniu do długości fali oświetlającej

Fig. 4. The generated power of the selected cells according to the wavelength of the light

Różnice w mocy generowanej przez badane ogniwa, skłoniły autora do wykonania dalszych pomiarów. Istniało przypuszczenie, że zaburzenia przenoszone przez warstwy powinny powodować spadek wydajności ogniw - a działo się zupełnie odwrotnie. W celu sprawdzenia zaburzeń w topografii autor wykonał 2 dodatkowe pomiary: a) mapowanie powierzchni pod kątem zmian wydajności (Rys. 5); b) obrazowanie AFM kolejnych powierzchni ogniw. Autor dobrał proces wykonania ogniw tak by po naniesieniu wszystkich warstw istniała możliwość indywidualnej analizy AFM każdej indywidualnie. Ze względów objętościowych w prezentowanym artykule umieszczono tylko obrazy AFM warstwy CdTe dla dwóch powiększeń.

Powierzchnie ogniw są takie same i ogniwo na szkle ma większą wydajność kwantową praktycznie w całym zakresie, pomimo tego ogniwo na laminacie generuje większą moc. Na mapie widać że te ogniwo na laminacie jest dużo bardziej jednorodne, ta moc generowana jest praktycznie maksymalnie na całym obszarze, a ogniwo na szkle, pomimo tego że w kilku punktach widocznych na mapie generuję większą moc, pozostała jego część jest prawie nieaktywna. Wymogi objętościowe tego artykułu nie pozwalają autorowi skupić się jedynie na wybranych fragmentach badań i przemyśleń dotyczących analizowanego zagadnienia. 
a)

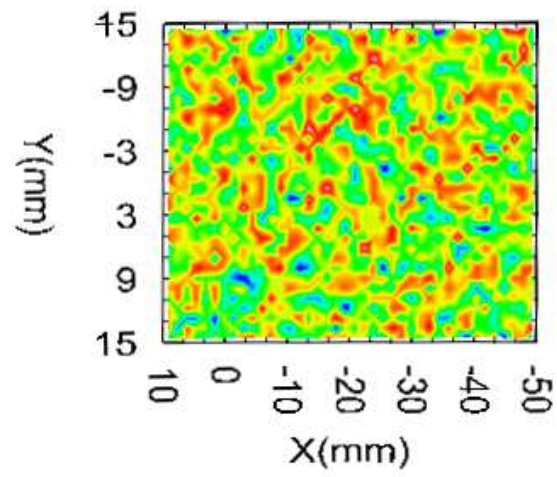

b)

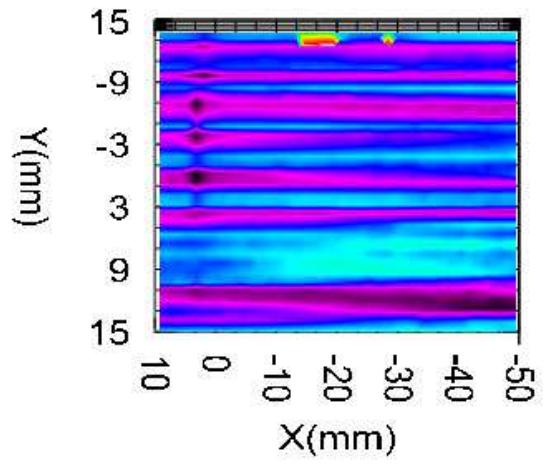

c)

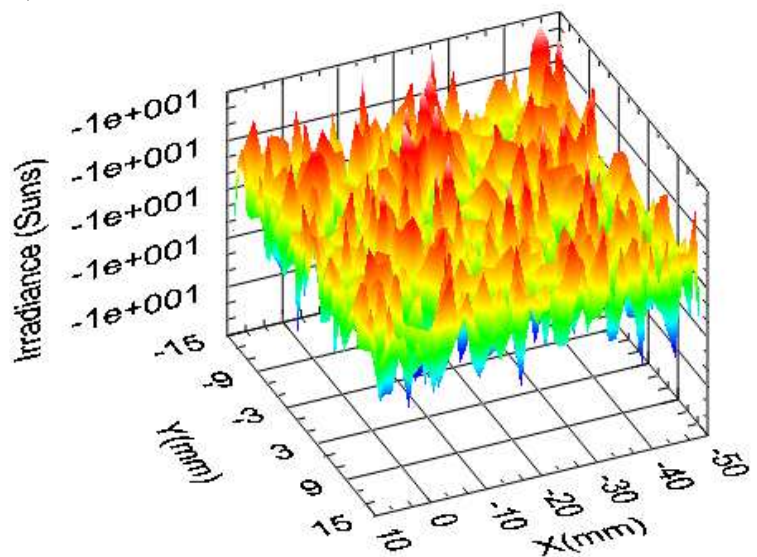

d)

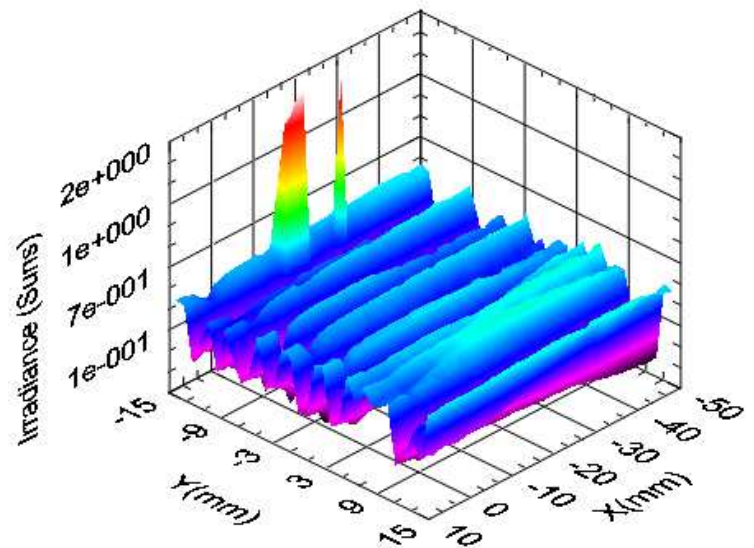

Rys. 5. Mapy wydajności wykonanych ogniw: a i c) podłoże laminat; b i d) podłoże szkło

Fig. 5. Mapping of the prepared cells: a, c) the laminate substrate; b, d) glass substrate 


\section{Wnioski}

1. Autorowi udało się uzyskać w pełni funkcjonujące ogniwo fotowoltaiczne na podłożu z laminatu papierowo żywicznym, które cechowało się bardzo zadowalającymi parametrami z punktu widzenia użytkowego.

2. Jakość (płaskorównoległość) kolejno nanoszonych warstw jest powieleniem struktury podłoża i może mieć wpływ na efektywność ogniw.

3. Potwierdzono wcześniejsze przypuszczenia (oraz prowadzone przez autora badania), wg. których fluktuacje warstwy absorpcyjnej mogą prowadzić do wzrostu powierzchni czynnej a tym samym zmian w efektywności [7].

4. Ze względu na obserwowane (Rys. 5) fluktuacje, tematyka wymaga dalszych badań - między innymi planuje się zwiększenie grubości kolejnych warstw, zastosowanie innych podłoży.

\section{Literatura}

[1] Sahin A., Kaya H., Thin-Film Solar Cells, 2010.

[2] Posadowski W. M.: Pulsed magnetron sputtering of reactive compounds, Thin Solid Films, 1999.

[3] Sławomir Gułkowski. Modelowanie charakterystyk I-V ogniw słonecznych w środowisku matlab/simulink. Czasopismo Inżynierii Lądowej, Środowiska i Architektury - Journal of Civil Engineering, Environment and Architecture, JCEEA, t. XXXI, z. 61 (3/II/14), 2014, s. 203-208, DOI:10.7862/rb.2014.88.

[4] Luhin V., Zarapin V., Zharski I., Zhukowski P.: Sensorowe właściwości cienkich warstw $\mathrm{SnO}_{2}$ wytwarzanych rozpylaniem magnetronowym, Elektronika. Konstrukcje, technologie, zastosowania 11/2011.

[5] Park M. W., Lee W. W,. Lee J. G,. Lee Ch. M, A Comparison of the Mechanical Properties of RF- and DC- Sputter-Deposited Cr Thin Films, Materials Science, 2007.

[6] Musil J., Baroch P., Vlcek J., Nam K.H., Han J.G.: Reactive magnetron sputtering of thin films: present and trends, Thin Solid Films, 2005.

[7] Krawczak E., Gułkowski S., Olchowik J. M.: Badanie efektywności pracy fotowolticznego systemu „off-grid” w warunkach zimowo-wiosennych dla Lubelszczyzny. Czasopismo Inżynierii Lądowej, Środowiska i Architektury - Journal of Civil Engineering, Environment and Architecture, JCEEA, t. XXXI, z. 61 (3/II/14), 2014, s. 317-328, DOI:10.7862/rb.2014.98.

\section{PHOTOVOLTAIC CELL ACTIVE SURFACE CHANGE USING SUBSTRATES WITH DIFFERENT TOPOGRAPHY PARAMETERS}

\section{S u m m a r y}

Magnetron Sputtering can create thin layers with can be used for electronic elements or photovoltaic cells [1,2]. The objective presented in the article concern the possibility of using photovoltaic cells substrates alternative to the commonly used. The author hypothesizes that the changes 
in the topography of the layers obtained by the sputtering magnetron are the consequence of disorders to the topography of the substrate. This disorder may result in a greater re-arrangement of the layer structure, leading to a more uniform after-surface, a phenomenon completely the opposite of what was thought. Both results are desirable in production applications. On the other hand, the most sought after result is the thin, uniform layers being the other layers of the modified topography. Disturbed layers can increase the active surface of the photovoltaic cell and thus increase its efficiency [3]. During the experiments, the author used as a base standard laboratory glass (float) and the laminate (paper with resin). There have been a series of thin layers of annotations, in order to obtain a complete cell. Cells on glass and the laminate was manufactured under the same conditions and parameters of other processes. Successive layers included in the construction of the cells to be applied so that it is possible subsequent analysis (using the appropriate aperture). After the cells were tested for quantum efficiency, which was related to the observation obtained by scanning successive layers of AFM.

Keywords: photovoltaic cells, layer topography modification, quantum efficiency, thin layer creation

DOI:10.7862/rb.2016.261

Przestano do redakcji: $30.06 .2016 r$.

Przyjęto do druku: 20.12.2016 r. 